\title{
A Review of UK-Registered and Candidate Vaccines for Bovine Respiratory Disease
}

\author{
Joanne L. Lemon ${ }^{1, *}$ and Michael J. McMenamy ${ }^{2}$ \\ 1 Sustainable Agri-Food and Sciences Division, Agri-Food and Bioscience Institute, Newforge Lane, \\ Belfast BT9 5PX, UK \\ 2 Veterinary Sciences Division, Agri-Food and Bioscience Institute, Stormont, Belfast BT4 3SD, UK; \\ michael.mcmenamy@afbini.gov.uk \\ * Correspondence: joanne.lemon@afbini.gov.uk
}

Citation: Lemon, J.L.; McMenamy, M.J. A Review of UK-Registered and Candidate Vaccines for Bovine Respiratory Disease. Vaccines 2021, 9, 1403. https://doi.org/10.3390/ vaccines 9121403

Academic Editor: Ralph A. Tripp

Received: 26 August 2021

Accepted: 22 November 2021

Published: 27 November 2021

Publisher's Note: MDPI stays neutral with regard to jurisdictional claims in published maps and institutional affiliations.

Copyright: (c) 2021 by the authors. Licensee MDPI, Basel, Switzerland. This article is an open access article distributed under the terms and conditions of the Creative Commons Attribution (CC BY) license (https:// creativecommons.org/licenses/by/ $4.0 /)$.

\begin{abstract}
Vaccination is widely regarded as a cornerstone in animal or herd health and infectious disease management. Nineteen vaccines against the major pathogens implicated in bovine respiratory disease are registered for use in the UK by the Veterinary Medicines Directorate (VMD). However, despite annual prophylactic vaccination, bovine respiratory disease is still conservatively estimated to cost the UK economy approximately $£ 80$ million per annum. This review examines the vaccine types available, discusses the surrounding literature and scientific rationale of the limitations and assesses the potential of novel vaccine technologies.
\end{abstract}

Keywords: vaccination; pathogens; efficacy; non-microbial risks; candidate

\section{Introduction}

Bovine respiratory disease complex (BRDC) is the principal cause of mortality in calves from 1-24 months of age across the world [1]. It has a significant impact on the global economy - the National Animal Disease Information Service (NADIS) estimates a cost to the UK alone of $£ 80$ million per annum, with over 1.9 million animals affected [2]. In the US this figure is estimated to be around $\$ 54.1$ million, with over $1 / 5$ th of cattle affected in any given year [3]. Additionally, BRDC is a recurring problem in many other parts of the world [4-7] and is widespread across Europe [8-11].

Costs involved can be both direct and incidental-from mortality, weight loss or carcass blemish and subsequent reduced market price to additional labour expenditure, housing modifications and prophylactic or therapeutic treatments [3,12-14]. Respiratory disease can occur throughout the year, however BRDC is largely seasonal in nature with outbreaks occurring within one month of housing in autumn or early winter, thus vaccination usually occurs in late summer [15].

Although the focus of this paper is the bovine respiratory disease complex, multiple coinfections or superinfections from numerous respiratory pathogens lead to similarly critical complexes in many other species, such as in pigs [16] sheep [17,18] dogs (also known as kennel cough) [19] and cats [20] and follows the same disease course. Initially, the immunosupression arising from stressors and bovine viral diarrhoea virus (BVDV) infection increases vulnerability and thus the likelihood of viral infection. Viral infection has a dual effect on disease progression-first, there is direct damage to the airway epithelial layer and mucociliary escalator, thereby increasing susceptibility to secondary bacterial infection; secondly, the immunosuppressive nature of viral infection can lead to a decrease in the potency of immune responses, thereby potentially increasing opportunity for bacterial pathogens to be inhaled deeply into the lungs, causing lower respiratory tract (LRT) disease [21-23]. Consequently, immunity is further suppressed, potentially aiding invasion from opportunistic non-commensal bacteria [16,24-26]. This results in bovine respiratory 
disease which presents as calf pneumonia. This concludes in either calf death or reduced growth after recovery.

Viral and bacterial microorganisms are the aetiological agents instigating BRD. Alongside, several non-microbial aspects have been identified as potential risk factors contributing to the risk of incidence of respiratory disease, discussed below. BRD is a multifaceted complex making it difficult to establish the exact contribution of each potential risk factor in decreasing resistance. However, all contributory risk factors act to elevate stress levels, reducing immunity and thus increase the susceptibility of cattle, particularly neonates [27]. Suitable alleviating mechanisms and infrastructures can reduce the severity and frequency of incidence of BRD:

(1) Housing: Housing, more specifically ventilation and stocking density, is often cited as the largest non-microbial risk factor for the development of BRD in 0-3 month old calves [28].

(2) Transport: There is a strong link between transport and BRDC-related morbidity [29]. In terms of both distance and method, transport is acknowledged as being a major stressor for cattle and calves are at the highest risk of developing respiratory disease just after shipment [30]. Often BRDC is referred to as 'shipping disease' for this reason.

(3) Weather: Sudden and extreme temperature changes may have more of an impact on the risk of bovine respiratory disease developing than continually high or low temperatures [30,31]. However, evidence of this is inconsistent [32,33].

(4) Farm management: Many farm management and animal husbandry practices increase the risk of bovine respiratory disease developing including pre-movement activities (dehorning, castration, weaning), comingling, vaccination status and intensity of farming $[34,35]$.

(5) Genetics: Various studies report Charolais, Simmental, Blonde d'Aquitaine and Aberdeen Angus bulls to have greater resistance to BRDC than other breeds [36]. Other authors have suggested that calves intended for use in the beef industry have a lower risk of developing BRD than those in the dairy industry, thought to be due to a greater microflora diversity and additional pathogen exposure through cattle markets [37]. Several groups are now using molecular techniques to identify genetically vulnerable animals [38-40].

The main contributory pathogens are detailed in Table 1, below. More recently, metagenomic analysis highlighted the involvement of up to 21 viruses in including bovine nidovirus, bovine parvovirus 3 and bovine rhinitis viruses [41]. Additionally it suggests the involvement of Influenza D virus-a newly identified virus, first detected in the UK in the winter of 2017 [42]. Frequently, the bacterial and viral pathogens associated with BRDC interact synergistically to enhance disease [43-45] although often the exact mechanisms remain unclear.

Table 1. Common viral and bacterial pathogens implicated in BRDC.

\begin{tabular}{ccc}
\hline Viruses & Bacteria & Mycoplasma spp. \\
\hline Bovine herpesvirus-1 (BHV-1) & Mannheimia (Pasteurella) & haemolytica \\
Bovine respiratory syncytial virus & Pasteurella multocida & Ureaplasma spp. \\
(BRSV) & Histophilus (Haemophilus) & \\
Bovine viral diarrhoea virus (BVDV) & somni \\
Bovine parainfluenza virus type-3 & & \\
(BPIV-3) & & \\
Bovine adenovirus (BAV) & & \\
Bovine coronavirus (BCoV) & & \\
\hline
\end{tabular}

Due to the complex aetiology surrounding the establishment of BRD it is difficult to ascertain the exact contribution of each pathogen. However, it is recognised that, on a global scale, seropositivity rates against all viral and bacterial associated with BRD are 
high and can sometimes be up to $100 \%$ Europe [46-50]. Clinical disease is frequently most severe in calves under 6 months of age, even in those with maternal antibodies [51].

\section{Currently Available Vaccines against BRD}

Nineteen vaccines against BRD are registered for use in the UK by the Veterinary Medicine Directorate [52]. Eight vaccines designed to target the viral and bacterial pathogens of BRD are multi or polyvalent and thus designed to target several pathogens in one vaccine, while 11 are monovalent (Appendix A; Tables A1 and A2). All vaccines available use whole virus, either modified live (attenuated) or inactivated, and all are administered by intramuscular, intranasal or subcutaneous routes.

\section{Limitations of Currently Available BRD Vaccines}

Ineffective vaccines, declining employment in the agricultural sector and increasing awareness of antimicrobial resistance has led policymakers to shift the focus onto the development of superior, more efficacious vaccines as a major contribution in reducing the pressure to intensify on the farming sector. Although many vaccines against BRD are currently available on the UK market, they have limitations. Only a few of the vaccines have been registered as suitable for use in pregnant or lactating cows and all require refrigeration. Additionally, all come with a strong recommendation for a booster to advance immunity and none have been tested for maternal antibody interference [52]. Only eleven of the vaccines registered for use in the UK are multivalent and only four have been tested and deemed suitable for use alongside other veterinary treatments, frequently with those of the same manufacturer. However, multiple pathogens are considered threats during the neonatal stage and so it is impractical and ineffectual to have monovalent or incompatible medicines. Vaccination against BRD presents many challenges:

\subsection{Age of Administration}

A major challenge to the development of a successful vaccines for BRD is the age at which calves must be vaccinated [53]. Peak viral infection occurs upwards from 1 month so vaccination must take place in the first few weeks of life to allow immunity to develop [54,55]. However, evidence shows a calf's immune system to be immature at this time, thought to be a carryover from the immunotolerant state induced during pregnancy $[53,56,57]$. To compound this problem, several essential farm management practices (discussed earlier) occur during this period increasing corticosteroid levels [30] and essential maternally-derived antibodies (MDA) may interfere with the development of any vaccine-induced immunity $[54,58]$.

\subsection{Route of Administration}

The majority of currently approved vaccines against BRD are to be used parenterally (i.e., sub-cutaneously or intramuscularly) and these have been demonstrated as producing protective immune responses [59-62]. However, parenteral vaccines are invasive, require trained personnel for sterile administration and often cause a 'depot effect' at the local site of injection; in cattle this can lead to carcass scarring and thus reduced price [63]. More recently, epicutaneous vaccination using skin patches, a non-invasive, needle-free delivery route, has been investigated in mice against RSV with encouraging results [64].

It has also been hypothesised that it might be more rational to vaccinate at the initial site of pathogen entry - intranasally - thereby potentially preventing infection at source. Many more intranasal vaccines are getting approved and coming onto the market. Intranasal vaccination induces more localised and protective mucosal immunity through activation of nasal-associated lymphoid tissues (NALT). Although mucosal immunity can also be generated as a consequence of vaginal, anal and oral inoculation, intranasal delivery is preferable due to its many advantages (discussed in context with disadvantages in Table 2). In support of this, a study by Ellis et al. showed that intranasal administration of BRSV vaccines intended for parenteral use did not reduce the protective efficacy of 
the vaccines [65]. Additionally, Rossi et al. [66] demonstrated strong bronchoalveolar cell-mediated and antibody responses after a single intranasal delivery of a multivalent BRSV, BHV-1 and BPIV-3 vaccine.

Table 2. Main advantages and disadvantages of intranasal vaccination in cattle.

Advantages
More neutral $\mathrm{pH}$ and lower levels of enzymatic activity than digestive tract
Prime neonatal calf in the presence of MDA
Needle-free/non-invasive
Induction of systemic and mucosal immunity
User-friendly (potential use in herds/developing world/remote farms)
Disadvantages
Rapid clearance of low affinity antigens
Potential antigen loss during inoculation (impact on cost)
Inefficient uptake
Lack of compatible adjuvants for mucosal vaccines

\subsection{Type of Vaccines Available:}

\subsubsection{Modified-Live (MLV) Vaccines}

Modified-live vaccines, also called attenuated vaccines, are those which employ live replicating whole pathogen that has been weakened in the laboratory. Attenuation of pathogenic strains can be obtained by modifying the molecular construction of the genome, using chemical mutagenesis, gene deletion or by extensive serial passaging in non-host cell culture or embryonated chick eggs. Chemical mutagenesis has also been coupled with low temperatures to develop a cold-adapted temperature-sensitive strain (ctss) of HRSV that can only replicate in the upper respiratory tract [67]. Only two diseases have been successfully eradicated across the globe-smallpox in humans [68] and rinderpest in cattle $[69,70]$ - and both have been achieved using modified-live vaccines, thus illustrating their significant contribution to human and veterinary health.

\subsubsection{Inactivated Vaccines}

Inactivated vaccines, also known as killed vaccines, are those which do not contain any live replicating pathogenic material and cannot cause disease. For this reason they have a superior safety profile to their live counterparts [71] and are considered suitable for use in pregnant or lactating animals. The pathogenic agents are destroyed by heat, chemicals or radiation. Furthermore, inactivated vaccines do not require refrigeration and can be lyophilised for transport purposes [72].

\subsubsection{Immunogenicity of Modified-Live and Inactivated Vaccines}

As attenuated vaccines broadly mimic the immune response garnered from a natural infection, they are universally recognised for producing stronger, longer lasting and more robust immune responses for many pathogens [72-75]. Furthermore, it is surmised that modified-live vaccines can initiate cellular responses in a way that inactivated vaccines are not reported as doing [76,77]. Several studies report the benefits of using modified-live vaccines in calves [78-81]. However, several studies now indicate that evidence on this is conflicting [81,82] and even if this were conclusive, often the immunogenicity advantages gained from MLV are offset by the increased safety risks posed, particularly in neonates.

Conversely, the immune response garnered from using inactivated vaccines is considered by some as inadequate with suggestions that inactivated vaccines can effectively prime CD4+ T cells but encourage eosinophila [83] and others providing evidence that IFN $\gamma$ expression is reduced [84]. A further study demonstrated a link between maternal vaccination for BVDV using inactivated vaccines and neonatal pancytopenia- a fatal autoimmune disease contracted from ingesting colostrum [85]. Further, although antibody titres can be high these are often found to be non-neutralising [86]. However, again, in 
contrast, several studies observed that using inactivated vaccines generated protection and they are at least as efficacious as using modified-live virus [83,87].

\subsubsection{Vaccine-Enhanced Disease}

Of particular note for BRSV is the observation that vaccination could actually augment disease. This was first noted in 1967 after a failed vaccine trail using a formalin-inactivated RSV (FI-RSV) vaccine against HRSV [88] which led to investigations in cattle where a similar pathology was reported $[89,90]$. In this study, one group was vaccinated with a FI-BRSV vaccine while the other was sham-vaccinated. Both groups were challenged with live BRSV post-vaccination. No significant difference in gross lung lesions and in lung function was noted between the two groups, indicating the failure of the vaccine to provide any protective immunity. Further, although two groups were challenged with the same amount of BRSV, the sham vaccinated cohort demonstrated lower mean clinical scores [90] indicating disease exacerbation arising from vaccination. High titres of non-neutralising antibodies have also been observed, which can be associated with a high IgE titres and an allergic, inflammatory Th2-type response [91] and it is hypothesised that disease escalation is attributed to FI-RSV generation of low affinity antibodies [92] targeted at non-protective epitopes. Consequently, apprehension surrounds trials employing inactivated vaccines and scientists are cautious about developing candidate vaccines using inactivated antigen. Although antibody titres generated from vaccination are not always correlated with reduced disease, vaccination against any other pathogen implicated in BRD does not appear to have had such a detrimental effect [30].

\subsection{Storage Conditions}

Incorrect vaccine storage is frequently cited as a main reason for vaccine failure [93]. Correct storage conditions are essential for conserving the three-dimensional structure of antigens, and thus essential for vaccines to retain their potency [94]. However, reliable vaccine storage is often not controlled for in a field setting. Vaccines which could potentially remain immunogenic outside of the cold chain (i.e., not refrigerated) would be greatly beneficial to remote regions, vast farms or areas lacking sufficient infrastructure [95]. Recently a candidate nanoparticle RSV vaccine derived from an Sf9 insect cell line has been trialled showing that, once re-suspended, the vaccine can remain stable for $<60$ days [96]. In further support of this, another group demonstrated that dry ice storage for up to 30 days did not detriment stability for a vaccine against East Coast fever-a tick-borne disease of cattle in Eastern and Central Africa with high mortality rates [97]. More recently a study into vaccines for tuberculosis showed that desiccation of liquid vaccine antigen increased thermostability outside of the cold-chain and produced a vaccine antigen more adaptable for mucosal use [98].

\section{Practical Considerations for Vaccine Development}

\subsection{Antimicrobial Medicines}

Metaphylaxis is a commonly employed tactic within farming, primarily utilised against mastitis in cattle, and dihydrostreptomycin, marbofloxacin or oxytetracycline are the most frequently detected antibiotics used in cattle [99]. Prophylactic treatment of calves with ceftiofur, rather than after the appearance of clinical signs was shown to reduce the incidence of BRD [100] further supporting this approach. However, this heavy reliance on antibiotics aggravated by the combination of agricultural intensification alongside ineffective vaccines has resulted in production systems coming under scrutiny as a source of escalating antimicrobial resistance. Globally, antimicrobial consumption in animal production is expected to increase by almost $70 \%$ by 2030 [101] despite comprehensive UK government efforts to curtail usage [102]. 


\subsection{EU Regulations}

Regulatory requirements for registering a veterinary vaccine within the EU are less stringent than those necessary to register a human vaccine; a process which is regulated by the Veterinary Medicines Directorate $[103,104]$. The legislative requirements are laid down in 2009/9/EC and/or by the World Organisation for Animal Health (OIE). Vaccine development is geared towards reducing animal use, with current investigations into in vitro potency assays [105] and in silico systems vaccinology [106].

Council directive 81/852/EEC and the European Pharmacopoeia further detail requirements, stating that results from laboratory efficacy trials should be supplemented with data from field efficacy trials [107]. However, when laboratory efficacy cannot be supported by field trials, in vitro data alone may be acceptable; this can particularly relevant for diseases which lack suitable experimental infection models (i.e., BRSV), with diseases that are caused by more than one aetiological agent or in certain diseases where environmental factors play a major role in disease development. The development of BRDC can be applied to any of these criteria [108]. Only two parameters need to be measured: clinical picture (mortality, morbidity, lesions, weigh) and the serological response, but evidence shows cell-mediated immunity to play an important role against bovine respiratory disease $[109,110]$.

\subsection{Veterinary Adjuvants}

Vaccines which are poorly immunogenic often require an additional stimulant as a component to augment efficacy. These can potentially reduce vaccine antigen loads or administration frequency [111] thus reducing production costs. Removal of the pathogenic fragments of BRSV to leave only purified antigens (i.e., a sub-unit vaccine) will increase the safety profile of the vaccine, increasing the tolerability. However, this can also lead to a reduction in the immunogenicity and the vaccine-induced immune response generated [112]. This balance between immunogenicity and safety is represented in Figure 1. Unlike human medicine, several adjuvants are registered for use in animal vaccines and all currently available vaccines employ aluminium compounds or variants. Despite its potent induction of cell-mediated immunity, the use of Complete or Incomplete Freund's Adjuvant (CFA/IFA) is strictly controlled in veterinary vaccines due to toxicity and the induction of painful side effects $[113,114]$. Montanide is emerging as a novel veterinary adjuvant suitable for use in cattle due to the higher lymphoproliferative and antibody responses observed in vaccines in which it is incorporated $[115,116]$. The area of research on adjuvants is expanding quickly and other adjuvants under investigation for use in cattle vaccines include IL-18 [117] poly(diaminosulfide) nanoparticles [118] and bovine IL17A [119].

\subsection{Vaccination Regimes}

Current vaccination regimes rely on a prime/boost regimen to obtain the greatest vaccine-induced immune response [120] and traditionally, boosting occurred with a homologous vaccine. Hill et al. demonstrated that intranasal vaccination of 3-6 week old calves using a modified-live BHV-1 vaccine followed by a booster with the same vaccine produced significantly higher IgA titres, reduced viral shedding and resulted in the least weight loss than a second vaccination with a heterologous (sub-cutaneous) vaccine [121]. However, other studies suggest that boosting with a heterologous vaccine can have a more beneficial effect as different arms of the immune system can be induced [122]. Important considerations are the vaccine antigen type [123] and the route of administration of the priming or boosting vaccine [124]. Due to the age at which BRD can develop and by extension the age at which vaccination is essential, induction of protective immunity following a single vaccine dose is highly desirable. Single dose vaccination has shown promising results in calves with MDA, using a modified live or recombinant BRSV vaccine administered intranasally or intramuscularly $[62,125,126]$. However, often little change is detected in 
virus neutralising antibodies (VNA) titres indicating that single inoculations may only be efficient at priming cell-mediated immunity [127].

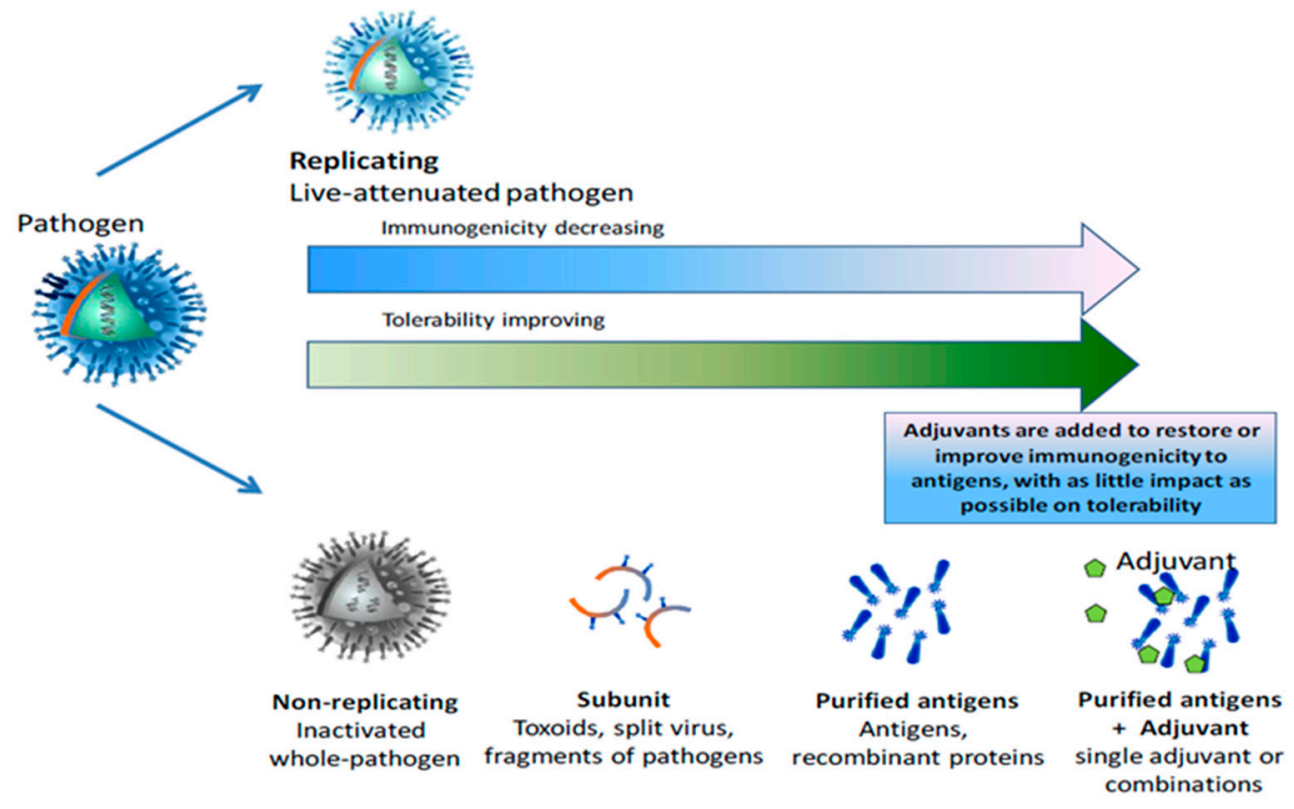

Figure 1. Vaccine antigen type consequence on vaccine safety and immunogenicity.

\subsection{Pre-Partum Vaccination}

Pre-partum vaccination of a heifer or cow is a farm management strategy successfully used to provide immunity for neonates, primarily against enteric pathogens such as Escherichia coli (E. coli), rotavirus or coronavirus $[128,129]$. Few report findings of maternal vaccination against BRD. However, Dudek et al. observed that maternal vaccination with a multivalent inactivated BRSV/BPIV-3/M. haemolytica vaccine, boosted colostrum immunoglobulin levels and led to increase in blood antibody titres in calves [130]. Additionally, it was reported that pre-partum vaccination positively impacted upon the antibody levels for BRSV, BHV-1, BVDV and BPIV-3. However, it was not considered significant enough to negate recommended neonatal vaccination schedules [131].

\section{Candidate BRD Vaccines}

Control strategies surrounding bovine respiratory disease concentrate on seasonal prophylactic antibiotic treatment and the administration of vaccines. Thus far these strategies have failed to prevent disease, with an estimated 1.9 million animals in the UK still affected by bovine respiratory disease annually. With increasing pressures on farms to intensify production alongside more rigid control on antibiotic use, research has focused on developing more efficacious, next generation vaccines.

\subsection{Peptide Vaccines}

There are currently no commercially available peptide vaccines for use in the veterinary field, despite the potential advantages in terms of ease of manufacture and flexibility. However, success has been reported for several candidate peptide vaccines and currently there is much interest in their use in human medicine, particularly against cancers [132], Human Immunodeficiency Virus [133] and diabetes [134]. In farm animals, Foot and Mouth Disease virus (FMDV) seems to command the largest share of research into peptide vaccines, in part due its status as a Specified Animal Pathogen Order (SAPO) level 4 infectious agent and of the economic impact of an outbreak $[135,136]$. Greenwood et al. describe using inert nanobeads conjugated with peptides from FMDV in sheep with higher antibody titres, increased TNF $\alpha$, IFN $\gamma$, IL- 6 and greater T cell proliferation observed in immunised animals [137]. Vaccines based on epitopes of the FMDV surface protein VP1 
have previously shown promise in swine [138] and Zhang et al. recently reported success with a peptide vaccine against FMDV detailing 100\% protection after prime/boost vaccination and challenge in cattle [139]. Bastien et al. reported a reduction in pathological lesions, compared to unvaccinated controls, when calves were immunised with a peptide encompassing BRSV G ${ }_{174-187}$ [140]. This had previously been shown to confer protection in mice [141]. Additionally, intraperitoneal immunisation of mice with a recombinant protein comprising HRSV $\mathrm{G}_{130-230}$ coupled to streptococcal $\mathrm{G}$ protein protected mice from upper and lower respiratory tract infection [142]. However, despite the induction of high antibody titres in these studies, they were non-neutralising; a result repeated in a later study [143] implying that peptide vaccines provide protection by means other than a humoral response.

\subsection{Immune Stimulatory Complexes (ISCOMs)}

ISCOMS are comprised of viral glycoproteins, cholesterol, phospholipids and nontoxic saponins from the bark of the Quillaja saponin tree (Quillaja saponaria). Tested using the surface antigens of HRSV and BRSV in guinea pigs [144] they have shown promise when used against BRSV in young calves with maternal antibodies [145]. Additionally, a bovine herpesvirus ISCOM vaccine demonstrated a high degree of immunogenicity when compared to the same BHV-1 proteins administered alone [146] and an ISCOM BVDV vaccine, which had previously been shown as protective in sheep, produced high serum neutralising titres when administered subcutaneously to calves [147].

\subsection{Virus-Like Particles (VLP)}

Virus-like particles (also known as pseudoviral particles) functionally and structurally resemble viruses and present viral antigens in a conformation more akin to a virion. As such, there is potential for lower antigenic doses to be used, reducing the cost of the vaccine-an important consideration in veterinary medicine [148]. As they do not contain genetic material they are non-infectious, non-replicating and safer than killed or attentuated vaccines. Although there is a lack of literature on VLPs for BRD, an early study demonstrated protection from clinical disease, significantly reduced leukopenia and led to the induction of cell-mediated and humoral immune responses when calves were immunised with a VLP containing BVDV 1b E2 glycoprotein antigens [149].

\subsection{Nanoparticle Vaccines}

To protect peptides from proteolytic degradation by cytosolic aminopeptidases they require formulation with an additional component such as carrier proteins or nanoparticles. Nanoparticles can be relatively inexpensive to manufacture, biodegradable non-toxic and can augment the immunogenicity of subunit vaccines, leading to a potential decrease in antigen load or administration frequency. Further benefits include controlled antigen release, providing protection to antigen in the unfavourable conditions provided by the respiratory tract and the potential removal of the cold chain necessary for vaccine storage [150]. Circular nanoring structures derived from a recombinant $\mathrm{N}$ protein of HRSV were used as a novel candidate vaccine against BRSV in young calves, with encouraging results [61]. A PLGA nanoparticle vaccine for BPIV-3 demonstrated higher IgA and serum IgG responses than those generated from a commercial vaccine, although there was no detection of any cell-mediated immunity [151]. Vaccines based on nanoparticles have also been associated with a reduced need for therapeutic intervention [152] and a recent review highlighted the benefits gained from using natural nanoparticles in livestock vaccines from a One Health perspective [153].

\subsection{DNA Vaccines}

DNA vaccines evolved in the 1990s [154] and have since shown success against many veterinary pathogens [155-157]. The principal behind a DNA vaccine is that sequence encoding a protein of interest from the pathogen involved will be ligated into bacterial 
plasmid DNA, which is transfected in vitro and transferred to a host for in vivo transcription to subsequently induce an immune response [158]. Intradermal vaccination using a DNA vaccine which expressed the E2 glycoprotein of BVDV resulted in strong BVDVspecific T-cell proliferation and a significant rise in antibody titres [159]. An early study of an intramuscular DNA vaccine against Influenza A observed proficient stimulation of $\mathrm{T}$ and $\mathrm{B}$ cell responses, indicating an ability to cross-present antigen [160]. However, only some have proved promising for neonatal vaccination against BRD in young calves with maternally-derived antibodies [161] — many have only been tested in seronegative calves [162]. Furthermore, B cell responses have been observed as being slower to develop and ultimately lower in VNA titres than those from natural infection [163] or using a vectored vaccine [163]. More recently, a decrease in clinical disease and viral shedding in conjunction with an increased IFNy and IgG response was noted after vaccination with a BHV-1 DNA vaccine [164]. With DNA vaccines, unlike protein-based vaccines, no mis-folding can occur. Additionally, when the production, storage, stability and safety advantages are taken into consideration alongside their proven ability to elicit both a cytotoxic and humoral response, it is clear this is an area worth researching more [165].

\subsection{Messenger RNA ( $m R N A$ ) Vaccines}

Messenger RNA vaccines are closely related to DNA vaccines with two major differencesfirstly, mRNA does not need to be processed through the nucleus but instead is released directly into the cytoplasm for transcription and secondly, the need for effective transfection is negated [166]. Essentially, mRNA vaccines remove an additional molecular step needed by DNA vaccines to accelerate the generation of vaccine-induced immunity. The only approved mRNA vaccines on the market at present are against SARS-CoV-2 infection, responsible for the Covid 19 pandemic [167] and mRNA vaccines have continued to show promise in clinical trials for Zika virus [168], Influenza A [169] and rabies in humans [170]. The absence of published data relating to the use of mRNA vaccines in farm animals, and more specifically against the pathogens implicated in BRDC, serves to highlight the newness of this area of research.

\subsection{Viral Vectors}

Viral vaccine vectors have been shown to capably induce robust cell mediated and humoral responses against Mannheimia haemolytica [171], BRSV [163], BHV-1 [172] and BVDV [173]. Unlike many other subunit vaccines often they do not require an adjuvant to boost immunity, instead relying on the inherent capability of a virus to enter and replicate in a cell. Poxvirus vectors show promise for multivalent vaccine use in cattle, due to the size of exogenous genes which can be accepted and they enjoy a superior safety profile due to their avian-restricted cytoplasmic replication. Vaccination with a recombinant modified Vaccinia virus Ankara (MVA) has shown much promise with BRSV [174] and its replicationdeficiency makes it all the more suitable for use in the field. Importantly, potential diseasecausing immunopathological reactions such as elevated IgE titres and eosinophil influx have not been observed in MVA vaccinated calves, post BRSV challenge [175]. Additionally, plant based vaccines are gaining prominence $[176,177]$ and have shown efficacy when tested against BVDV [178]. Bovine respiratory pathogens are often used as vectors for other bovine respiratory pathogens-bovine herpesvirus-type 1 (BHV-1) has been successfully used against BRSV in calves reducing clinical signs, pneumonic lesions and viral loads despite low antibody titres [179] and a recombinant Pasteurella multocida vector has been shown to provide protection against Mannheimia haemolytica [180]. The majority of candidate vaccines using bovine respiratory pathogens as viral vectors focus on bovine RSV-as the model of BRSV disease in calves mirrors that of RSV infection in infants, this can be considered a reflection of the medical urgency for a human RSV vaccine. 


\section{Conclusions}

Bovine respiratory disease is a major threat to dairy and beef farming on a global scale and is the leading cause of mortality and morbidity in cattle over 1 month of age [181]. Currently, the commercially available vaccines against BRD are limited in their efficacy, as evidenced by the development of clinical disease regardless of vaccination. This is despite advances in understanding pathogenesis, aetiological agents, vaccine technologies and biosecurity measures [3]. This limited efficacy may be due to a combination inappropriate administration routes, unsuitable vaccine storage and the challenges of inoculating in young calves. Further, major obstacles in successful vaccine design can come from a combination of host immunity factors, pathogen characteristics and necessary on-farm practices.

However, on a global scale the population is projected to grow exponentially with an estimated $70-100 \%$ increase in food production required to satisfy this growth [182]. To compound the problem of food security from rising demand, employment in agriculture has been on the decline since the 1900s $[183,184]$. The demand for additional food from fewer resources is a problem intrinsically linked to socio-economics, climate change, agriculture and resource or land use [185].

The UK relies heavily on agriculture as a source of income for the economy-in 2020 the total income from farming was estimated to be $£ 4119$ million [186]. Using Northern Ireland as an example, agriculture accounts for $1.7 \%$ of Gross Value Added (GVA), approximately 3 times above the UK average, and has been identified as a key future source of economic development in the 'Going for Growth' agri-food strategy [187]. However, the intensification necessary to realise this drive for economic growth has resulted in increasing farm size against a backdrop of decreasing farm numbers [188] and this intensification in productivity may lead to an increasing vulnerability to infectious disease. Thus, alongside increasing pressure on farms to intensify production and more rigid control on antibiotic use, research continues to focus on developing more efficacious, next generation vaccines [189].

Author Contributions: Conceptualization: J.L.L.; writing—original draft preparation: J.L.L.; writing review and editing: J.L.L. and M.J.M. All authors have read and agreed to the published version of the manuscript.

Funding: This research received no external funding

Institutional Review Board Statement: Not applicable.

Informed Consent Statement: Not applicable.

Data Availability Statement: The data presented in this study are collected from the cited literature.

Conflicts of Interest: The authors declare no conflict of interest.

\section{Appendix A}

Table A1. Monovalent vaccines for bovine respiratory disease.

\begin{tabular}{|c|c|}
\hline - Name: & Bovalto Pastobov (2007; Vm 08327/4173) \\
\hline Multivalent: & $\begin{array}{c}\mathrm{N}-\text { Mannheimia haemolytica (formerly Pasteurella } \\
\text { haemolytica) }\end{array}$ \\
\hline Antigen: & Type A1 \\
\hline Recommended age: & Minimum 4 weeks, booster 28 days later \\
\hline Route of administration: & Sub-cutaneous or intramuscular \\
\hline Adjuvant/excipients: & Aluminium hydroxide $(4.2 \mathrm{mg})$, thiomersal, salts, water \\
\hline
\end{tabular}


Table A1. Cont.

\begin{tabular}{cc} 
- & Bovela lyophilisate (EU/2/14/176/001-016) \\
\hline Multivalent: & N-BVDV (1—non cyto KE-9; 2—non cyto NY-93) \\
\hline Antigen: & Modified live (both strains) \\
\hline Recommended age: & 3 months + \\
\hline Route of administration: & Intramuscular \\
\hline Adjuvant/excipients: & Not detailed \\
\hline Name: & Bovilis BVDV suspension (1999; Vm06376/4025) \\
\hline Multivalent: & N-BVDV 1 (non cyto C-86) \\
\hline Antigen: & Inactivated \\
\hline Recommended age: & 8 months \\
\hline Route of administration: & Intramuscular \\
\hline Adjuvant/excipients: & Aluminium 3+ (Alum hydroxide) 6-9 mg
\end{tabular}

- $\quad$ Name:

BOVILIS IBR marker inac (2006; vm06376/4053)

\begin{tabular}{cc}
\hline Multivalent: & $\mathrm{N}-\mathrm{BHV}-1$ (GK/D gE negative strain) \\
\hline Antigen: & Inactivated \\
\hline Recommended age: & 3 months onwards \\
\hline Route of administration: & Intramuscular \\
\hline Adjuvant/excipients: & Alum $3+(6.0-8.8 \mathrm{mg})$ formaldehyde $0.6-1 \mathrm{mg}$, trometamol
\end{tabular}

Adjuvant/excipients: $\quad$ Alum $3+(6.0-8.8 \mathrm{mg})$ formaldehyde $0.6-1 \mathrm{mg}$, trometamol

- Name

BOVILIS IBR MARKER LIVE (2006, vm06376/4032)

\begin{tabular}{cc}
\hline Multivalent: & N-BHV-1 (GK/D strain, gE negative) \\
\hline Antigen: & Live \\
\hline Recommended age: & $2 \mathrm{wk}$ (Intranasal) $12 \mathrm{wk}$ (Intramuscular) \\
\hline Route of administration: & Intranasal or Intramuscular \\
\hline Adjuvant/excipients: & Sorbitol, monosodium glutamate; glycine \\
\hline
\end{tabular}

- Name:

HIPRABOVIS IBR marker live (2011; eu/2/10/114/001)

\begin{tabular}{cc}
\hline Multivalent: & N-BHV-1 (gE deleted; Ceddel strain) \\
\hline Antigen: & Live \\
\hline Recommended age: & Intramuscular \\
\hline Route of administration: & Not disclosed \\
\hline Adjuvant/excipients: & NASYM (EU/2/19/241/001-004 \\
\hline Name: & N—BRSV (LYM-56) \\
\hline Multivalent: & Live \\
\hline Antigen: & 9d (Intranasal) 10w (intramuscular) \\
\hline Recommended age: & Intranasal OR Intramuscular \\
\hline Route of administration: & Not disclosed
\end{tabular}


Table A1. Cont.

- Name:

\begin{tabular}{|c|c|}
\hline Multivalent: & N-BHV-1 (gE deleted, Difivac Strain) \\
\hline Antigen: & Inactivated \\
\hline Recommended age: & $2 \mathrm{w}-3 \mathrm{~m}$ (if later than use 3rd booster) \\
\hline Route of administration: & Sub cut Sub-cutaneous \\
\hline Adjuvant/excipients: & QUIL A (0.25 MG) ALUM HYDROX (14-24 MG) \\
\hline - Name: & Rispoval Pateurella (VM42058/4128, 1999) \\
\hline Multivalent: & N-Man.H type A1 (NL 1009 strain) \\
\hline Antigen: & Inactivated \\
\hline Recommended age: & $12 \mathrm{wk}+$ \\
\hline Route of administration: & Intramuscular \\
\hline Adjuvant/excipients: & Liquid paraffin and alum hydrox \\
\hline - Name: & Rispoval RS (vm 42058/4129, 2005) \\
\hline Multivalent: & $\mathrm{N}-\mathrm{BRSV}$ (RB94) \\
\hline Antigen: & Live attenuated \\
\hline Recommended age: & $7 \mathrm{~d}-4 \mathrm{~m}$ (If $7 \mathrm{~d}$ then $3 \mathrm{rd}$ booster to counteract MDA) \\
\hline Route of administration: & Intramuscular \\
\hline Adjuvant/excipients: & Not detailed \\
\hline - Name: & Tracherine (VM42058/4156; 2010) \\
\hline Multivalent: & N-IBR (RBL106) \\
\hline Antigen: & Live attenuated \\
\hline Recommended age: & 3w (10 wk ideally for reduced MDA interference) \\
\hline Route of administration: & Intranasal \\
\hline Adjuvant/excipients: & Not detailed \\
\hline
\end{tabular}

Table A2. Poly/Multivalent vaccines for bovine respiratory disease.

\begin{tabular}{cc} 
- Name: & Bovalto Respi 3 (2016) (Vm 08327/4273) \\
\hline Multivalent: & Y-BRSV (BiO-24) and BPIV-3 (BiO-23) Man.H \\
$(\mathrm{A} 1)$
\end{tabular}


Table A2. Cont.

\begin{tabular}{|c|c|}
\hline - $\quad$ Name: & Bovalto Respi 4 (2016; Vm 08327/4274) \\
\hline Multivalent: & $\begin{array}{c}\text { Y-BRSV (BiO24) BBPIV-3V (Bio23) Man H } \\
\text { (A1) BVDVV (Bio25) }\end{array}$ \\
\hline Antigen: & All inactivated \\
\hline Recommended age: & $2 \mathrm{wk}+$ \\
\hline Route of administration: & Sub-cutaneous \\
\hline Adjuvant/excipients: & $\begin{array}{c}\text { AH (8.0 mg) Quil A }(0.4 \mathrm{mg}) \text { Thiomersal (0.2 } \\
\text { mg) Formaldehyde (1.0 mg) }\end{array}$ \\
\hline - Name: & $\begin{array}{l}\text { Bovalto Respi Intranasal (2018; Vm } \\
\text { 08327/4289) }\end{array}$ \\
\hline Multivalent: & Y-BPIV-3 (Bio23/A) BRSV (Bio24/A) \\
\hline Antigen: & Modified live (both) \\
\hline Recommended age: & 10 day + \\
\hline Route of administration: & Intranasal \\
\hline Adjuvant/excipients: & Not detailed \\
\hline - $\quad$ Name: & Bovilis bovipast rsp (1999; Vm 01708/4458) \\
\hline Multivalent: & $\begin{array}{c}\text { Y-BRSV (ev908) BPIV-3 (sf-4 reisinger) Man.H } \\
\text { A1 (cross reactive to A6) }\end{array}$ \\
\hline Antigen: & All inactivated \\
\hline Recommended age: & $\sim 2$ wks of age, prior to housing \\
\hline Route of administration: & Sub-cutaneous \\
\hline Adjuvant/excipients: & $\begin{array}{l}\text { Alum hydr (37.5 mg) Quil A (0.625 mg) } \\
\text { Thiomersal (0.032-0.58 mg) }\end{array}$ \\
\hline - Name: & IMURESP-RP (vm 42058/4072 2005) \\
\hline Multivalent: & Y-BPIV-3 (ts RLB103) IBR (ts RLB106) \\
\hline Antigen: & Live attenuated \\
\hline Recommended age: & 3-10 wk but $10+$ wk preferred \\
\hline Route of administration: & Intranasal \\
\hline Adjuvant/excipients: & Not disclosed \\
\hline - Name: & Rispoval 3 (vm 42058/4124; 2005) \\
\hline Multivalent: & $\begin{array}{l}\text { Y-BPIV-3 (RLB103) BRSV (375) BVDVV (type } \\
15960 \mathrm{c}+6309 \mathrm{n}-\mathrm{c})\end{array}$ \\
\hline Antigen: & $\begin{array}{c}\text { Modified live (BPIV-3, BRSV) inactivated } \\
\text { BVDV }\end{array}$ \\
\hline Recommended age: & $12 \mathrm{wk}+$ \\
\hline Route of administration: & Intramuscular \\
\hline Adjuvant/excipients: & $\begin{array}{c}\text { Alhydrogel } 2 \% 0.8 \mathrm{~mL} \text { (equiv. of } 24.36 \mathrm{mg} \\
\text { alum hydroxide) }\end{array}$ \\
\hline
\end{tabular}


Table A2. Cont.

\begin{tabular}{cc}
\hline - Name: & Rispoval 4 (VM42058/4125, 2001) \\
\hline Multivalent: & Y-As above (17) including IBR/BHV-1 \\
\hline Antigen: & Inactivated \\
\hline Recommended age: & 12 wk + \\
\hline Route of administration: & Intramuscular \\
\hline Adjuvant/excipients: & Not detailed \\
\hline Name: & Rispoval RS + BPIV-3 (VM42058/4130) \\
\hline Multivalent: & Y-BRSV (375) and BPIV-3 (ts RLB103) \\
\hline Antigen: & Modified Live \\
\hline Recommended age: & 9 day + \\
\hline Route of administration: & Intranasal \\
\hline Adjuvant/excipient: & Not disclosed \\
\hline ts = temperature sensitive; c = cytopathic, $\mathrm{n}$-c $=$ non-cytopathic.
\end{tabular}

\section{References}

1. Callan, R.J.; Garry, F.B. Biosecurity and bovine respiratory disease. Veter. Clin Food Anim. Pract. 2002, 18, 57-77. [CrossRef]

2. Scott, P. Respiratory Disease in Dairy and Beef Rearer Units. 2016. Available online: www.nadis.org.uk/4804 (accessed on 17 November 2018).

3. Johnson, K.K.; Pendell, D.L. Market Impacts of Reducing the Prevalence of Bovine Respiratory Disease in United States Beef Cattle Feedlots. Front. Veter. Sci. 2017, 4, 189. [CrossRef] [PubMed]

4. Blakebrough-Hall, C.; Mcmeniman, J.P.; González, L.A. Economics of Animal Production: An evaluation of the economic effects of bovine respiratory disease on animal performance, carcass traits and economic outcomes in feedlot cattle defined using four BRD diagnosis methods. J. Anim. Sci. 2020, 98,1-11. [CrossRef]

5. Kamdi, B.; Singh, R.; Singh, V.; Singh, S.; Kumar, P.; Singh, K.P.; George, N.; Dhama, K. Immunofluorescence and molecular diagnosis of bovine respiratory syncytial virus and bovine parainfluenza virus in the naturally infected young cattle and buffaloes from India. Microb. Pathog. 2020, 145, 104165. [CrossRef]

6. Timsit, E.; Workentine, M.; van der Meer, F.; Alexander, T. Distinct bacterial metacommunities inhabit the upper and lower respiratory tracts of healthy feedlot cattle and those diagnosed with bronchopneumonia. Veter. Microbiol. 2018, 221, 105-113. [CrossRef] [PubMed]

7. Kurćubić, V.; Đoković, R.; Ilić, Z.; Petrović, M. Etiopathogenesis and economic significance of bovine respiratory disease complex (BRDC). Acta Agric. Serbica 2018, 23, 85-100. [CrossRef]

8. Delabouglise, A.; James, A.; Valarcher, J.F.; Hägglund, S.; Raboisson, D.; Rushton, J. Linking disease epidemiology and livestock productivity: The case of bovine respiratory disease in France. PLoS ONE 2017, 12, e0189090. [CrossRef] [PubMed]

9. Kudirkiene, E.; Aagaard, A.K.; Schmidt, L.M.; Pansri, P.; Krogh, K.M.; Olsen, J.E. Occurrence of major and minor pathogens in calves diagnosed with bovine respiratory disease. Veter. Microbiol. 2021, 259, 109135. [CrossRef] [PubMed]

10. Steiner, A.; Meylan, M.; Lava, M.; Schüpbach, G. Antimicrobial drug use and risk factors associated with treatment incidence and mortality in Swiss veal calves reared under improved welfare conditions. Prev. Vet. Med. 2016, 126, 121-130. [CrossRef]

11. Makoschey, B.; Berge, A.C. Review on bovine respiratory syncytial virus and bovine parainfluenza - usual suspects in bovine respiratory disease-A narrative review. BMC Veter. Res. 2021, 17, 1-18. [CrossRef] [PubMed]

12. Bell, C.J.; Blackburn, P.; Elliott, M.; Patterson, T.I.A.P.; Ellison, S.; Lahuerta-Marin, A.; Ball, H.J. Investigation of polymerase chain reaction assays to improve detection of bacterial involvement in bovine respiratory disease. J. Veter. Diagn. Investig. 2014, 26, 631-634. [CrossRef] [PubMed]

13. Baptista, A.L.; Rezende, A.L.; Fonseca, P.D.A.; Massi, R.P.; Nogueira, G.M.; Magalhães, L.Q.; Headley, S.A.; Menezes, G.L.; Alfieri, A.A.; Saut, J.P.E. Bovine respiratory disease complex associated mortality and morbidity rates in feedlot cattle from southeastern Brazil. J. Infect. Dev. Ctries. 2017, 11, 791-799. [CrossRef] [PubMed]

14. Glover, I.D. Improving calf-side diagnosis of respiratory disease on UK dairy farms. Livestock 2017, 22, 230-238. [CrossRef]

15. Cavirani, S. Immunization of calves and herd immunity to Bovine respiratory Disease Complex (BRDC). Large Anim. Rev. 2019, 25, 17-24.

16. Saade, G.; Deblanc, C.; Bougon, J.; Marois-Créhan, C.; Fablet, C.; Auray, G.; Belloc, C.; Leblanc-Maridor, M.; Gagnon, C.A.; Zhu, J.; et al. Coinfections and their molecular consequences in the porcine respiratory tract. Veter. Res. 2020, 51, 1-19. [CrossRef] 
17. Tibbo, M.; Woldemeskel, M.; Gopilo, A. An outbreak of respiratory disease complex in sheep in Central Ethiopia. Trop. Anim. Health Prod. 2001, 33, 355-365. [CrossRef] [PubMed]

18. Scott, P.R. Treatment and Control of Respiratory Disease in Sheep. Veter. Food Anim. Pract. 2011, 27, 175-186. [CrossRef]

19. Reagan, K.L.; Sykes, J.E. Canine Infectious Respiratory Disease. Veter. Food Anim. Pract. 2020, 50, 405-418. [CrossRef] [PubMed]

20. Cohn, L.A. Feline Respiratory Disease Complex. Veter. Clin. N. Am. Anim. Pract. 2011, 41, 1273-1289. [CrossRef]

21. Bryson, D. Calf Pneumonia. Veter. Clin. N. Am. Food Anim. Pract. 1985, 1, 237-257. [CrossRef]

22. Larsen, L.E.; Tegtmeier, C.; Pedersen, E. Bovine respiratory syncytial virus (BRSV) pneumonia in beef herds despite vaccination. Acta Veter. Scand. 2001, 42, 113-121. [CrossRef] [PubMed]

23. Gershwin, L.J.; Berghaus, L.J.; Arnold, K.; Anderson, M.L.; Corbeil, L.B. Immune mechanisms of pathogenetic synergy in concurrent bovine pulmonary infection with Haemophilus somnus and bovine respiratory syncytial virus. Veter. Immunol. Immunopathol. 2005, 107, 119-130. [CrossRef] [PubMed]

24. Beadling, C.; Slifka, M.K. How do viral infections predispose patients to bacterial infections? Curr. Opin. Infect. Dis. 2004, 17, 185-191. [CrossRef] [PubMed]

25. Manohar, P.; Loh, B.; Athira, S.; Nachimuthu, R.; Hua, X.; Welburn, S.C.; Leptihn, S. Secondary Bacterial Infections During Pulmonary Viral Disease: Phage Therapeutics as Alternatives to Antibiotics? Front. Microbiol. 2020, 11, 1434. [CrossRef]

26. Bell, R.; Turkington, H.; Cosby, S. The Bacterial and Viral Agents of BRDC: Immune Evasion and Vaccine Developments. Vaccines 2021, 9, 337. [CrossRef] [PubMed]

27. Hulbert, L.E.; Moisá, S.J. Stress, immunity, and the management of calves. J. Dairy Sci. 2016, 99, 3199-3216. [CrossRef]

28. Van der Fels-Klerx, H.; Horst, H.; Dijkhuizen, A. Risk factors for bovine respiratory disease in dairy youngstock in The Netherlands: The perception of experts. Livest. Prod. Sci. 2000, 66, 35-46. [CrossRef]

29. Pinchak, W.E.; Tolleson, D.R.; McCloy, M.; Hunt, L.J.; Gill, R.J.; Ansley, R.J.; Bevers, S.J. Morbidity effects on productivity and profitability of stocker cattle grazing in the Southern Plains. J. Anim. Sci. 2004, 82, 2773-2779. [CrossRef]

30. Taylor, J.D.; Fulton, R.W.; Lehenbauer, T.W.; Step, D.L.; Confer, A.W. The epidemiology of bovine respiratory disease: What is the evidence for preventive measures? Can. Veter. J. 2010, 51, 1351-1359, PMCID:PMC2978987.

31. Ribble, C.S.; Meek, A.H.; Janzen, E.D.; Guichon, P.T.; Jim, G.K. Effect of time of year, weather, and the pattern of auction market sales on fatal fibrinous pneumonia (shipping fever) in calves in a large feedlot in Alberta (1985-1988). Can. J. Veter. Res. 1995, 59, 167-172, PMCID:PMC1263760.

32. MacVean, D.W.; Franzen, D.K.; Keefe, T.J.; Bennett, B.W. Airborne particle concentration and meteorologic conditions associated with pneumonia incidence in feedlot cattle. Am. J. Veter. Res. 1986, 47, 2676-2682. [PubMed]

33. Alexander, B.H.; MacVean, D.W.; Salman, M.D. Risk factors for lower respiratory tract disease in a cohort of feedlot cattle. J. Am. Veter. Med Assoc. 1989, 195, 207-211. [PubMed]

34. Härtel, H.; Nikunen, S.; Neuvonen, E.; Tanskanen, R.; Kivelä, S.-L.; Aho, P.; Soveri, T.; Saloniemi, H. Viral and Bacterial Pathogens in Bovine Respiratory Disease in Finland. Acta Veter. Scand. 2004, 45, 193-200. [CrossRef]

35. Hay, K.; Morton, J.; Schibrowski, M.; Clements, A.; Mahony, T.; Barnes, T. Associations between prior management of cattle and risk of bovine respiratory disease in feedlot cattle. Prev. Veter. Med. 2016, 127, 37-43. [CrossRef]

36. Hägglund, S.; Hjort, M.; Graham, D.; Öhagen, P.; Törnquist, M.; Alenius, S. A six-year study on respiratory viral infections in a bull testing facility. Veter. J. 2007, 173, 585-593. [CrossRef] [PubMed]

37. Hotchkiss, E.J.; Dagleish, M.P.; Willoughby, K.; McKendrick, I.J.; Finlayson, J.; Zadoks, R.N.; Newsome, E.; Brulisauer, F.; Gunn, G.J.; Hodgson, J.C. Prevalence of Pasteurella multocidaand other respiratory pathogens in the nasal tract of Scottish calves. Veter. Rec. 2010, 167, 555-560. [CrossRef] [PubMed]

38. Neibergs, H.L.; Seabury, C.M.; Wojtowicz, A.J.; Wang, Z.; Scraggs, E.; Kiser, J.N.; Neupane, M.; E Womack, J.; Van Eenennaam, A.; Hagevoort, G.R.; et al. Susceptibility loci revealed for bovine respiratory disease complex in pre-weaned holstein calves. BMC Genom. 2014, 15, 1-19. [CrossRef] [PubMed]

39. Johnston, D.; Earley, B.; McCabe, M.S.; Lemon, K.; Duffy, C.; McMenamy, M.; Cosby, S.L.; Kim, J.; Blackshields, G.; Taylor, J.; et al. Experimental challenge with bovine respiratory syncytial virus in dairy calves: Bronchial lymph node transcriptome response. Sci. Rep. 2019, 9, 1-13. [CrossRef] [PubMed]

40. Johnston, D.; Earley, B.; McCabe, M.S.; Kim, J.; Taylor, J.F.; Lemon, K.; Duffy, C.; McMenamy, M.; Cosby, S.L.; Waters, S.M. Messenger RNA biomarkers of Bovine Respiratory Syncytial Virus infection in the whole blood of dairy calves. Sci. Rep. 2021, 11, 1-7. [CrossRef]

41. Mitra, N.; Cernicchiaro, N.; Torres, S.; Li, F.; Hause, B. Metagenomic characterisation of the virome associated with bovine respiratory disease in feedlot cattle identified novel viruses and suggests an etiologic role for influenza D virus. J. Gen. Virol. 2016, 97, 1771-1784. [CrossRef] [PubMed]

42. Dane, H.; Duffy, C.; Guelbenzu, M.; Hause, B.; Fee, S.; Forster, F.; McMenamy, M.J.; Lemon, K. Detection of influenza D virus in bovine respiratory disease samples, UK. Transbound. Emerg. Dis. 2019, 66, 2184-2187. [CrossRef]

43. Ellis, J.A. Update on viral pathogenesis in BRD. Anim. Health. Res. Rev. 2009, 10, 149-153. [CrossRef] [PubMed]

44. Prysliak, T.; van der Merwe, J.; Lawman, Z.; Wilson, D.; Townsend, H. Respiratory disease caused by Mycoplasma bovis is enhanced by exposure to bovine herpes virus 1 (BHV-1) but not to bovine viral diarrhea virus (BVDV) type 2. Can. Veter. J. 2011, 52, 1195, ISSN: 0008-5286. 
45. Fahkrajang, W.; Sudaryatma, P.E.; Mekata, H.; Hamabe, S.; Saito, A.; Okabayashi, T. Bovine respiratory coronavirus enhances bacterial adherence by upregulating expression of cellular receptors on bovine respiratory epithelial cells. Veter. Microbiol. 2021, 255, 109017. [CrossRef] [PubMed]

46. Ohlson, A.; Alenius, S.; Tråvén, M.; Emanuelson, U. A longitudinal study of the dynamics of bovine corona virus and respiratory syncytial virus infections in dairy herds. Veter. J. 2013, 197, 395-400. [CrossRef] [PubMed]

47. Uttenthal, Å.; Larsen, L.E.; Philipsen, J.S.; Tjørnehøj, K.; Viuff, B.; Nielsen, K.H.; Nielsen, T.K. Antibody dynamics in BRSV-infected Danish dairy herds as determined by isotype-specific immunoglobulins. Veter. Microbiol. 2000, 76, 329-341. [CrossRef]

48. Collins, J.; Teegarden, R.; MacVean, D.; Salman Smith, G.; Frank, G. Prevalence and specificity of antibodies to bovine respiratory syncytial virus in sera from feedlot and range cattle. Am. J. Veter. Res. 1988, 49, 1316-1319. [PubMed]

49. Obando, R.; Hidalgo, M.; Merza, M.; Montoya, A.; Klingeborn, B.; Moreno-López, J. Seroprevalence to bovine virus diarrhoea virus and other viruses of the bovine respiratory complex in Venezuela (Apure State). Prev. Veter. Med. 1999, 41, 271-278. [CrossRef]

50. Solís-Calderón, J.; Segura-Correa, J.; Aguilar-Romero, F.; Segura-Correa, V. Detection of antibodies and risk factors for infection with bovine respiratory syncytial virus and parainfluenza virus-3 in beef cattle of Yucatan, Mexico. Prev. Veter. Med. 2007, 82, 102-110. [CrossRef] [PubMed]

51. Kimman, T.G.; Westenbrink, F.; Schreuder, B.E.; Straver, P.J. Local and systemic antibody response to bovine respiratory syncytial virus infection and reinfection in calves with and without maternal antibodies. J. Clin. Microbiol. 1987, 25, 1097-1106. [CrossRef] [PubMed]

52. National Office of Animal Health. Compendium of Data Sheets for Animal Medicines 2021; National Office of Animal Health: Enfield, UK, 2021; 1584p.

53. Chase, C.C.; Hurley, D.J.; Reber, A.J. Neonatal Immune Development in the Calf and Its Impact on Vaccine Response. Veter. Clin. N. Am. Food Anim. Pract. 2008, 24, 87-104. [CrossRef]

54. Niewiesk, S. Maternal Antibodies: Clinical Significance, Mechanism of Interference with Immune Responses, and Possible Vaccination Strategies. Front. Immunol. 2014, 5, 446. [CrossRef]

55. Richeson, J.T.; Falkner, T.R. Bovine Respiratory Disease Vaccination: What Is the Effect of Timing? Veter. Clin. N. Am. Food Anim. Pract. 2020, 36, 473-485. [CrossRef] [PubMed]

56. Cortese, V.S. Neonatal Immunology. Veter. Clin. N. Am. Food Anim. Pract. 2009, 25, 221-227. [CrossRef] [PubMed]

57. Tregoning, J.S.; Wang, B.L.; McDonald, J.U.; Yamaguchi, Y.; Harker, J.A.; Goritzka, M.; Openshaw, P.J. Neonatal antibody responses are attenuated by interferon- $\gamma$ produced by NK and T cells during RSV infection. Proc. Natl. Acad. Sci. USA 2013, 110, 5576-5581, PMCID:PMC3619373. [CrossRef]

58. Ellis, J.; Gow, S.; Bolton, M.; Burdett, W.; Nordstrom, S. Inhibition of priming for bovine respiratory syncytial virus-specific protective immune responses following parenteral vaccination of passively immune calves. Can. Veter. J. 2014, 55, 1180-1185.

59. Gershwin, L.J.; Behrens, N.E.; McEligot, H.A.; Carvallo-Chaigneau, F.R.; Crum, L.T.; Gunnarson, B.M.; Corbeil, L.B. A recombinant subunit vaccine for bovine RSV and Histophilus somni protects calves against dual pathogen challenge. Vaccine 2017, 35, 1954-1963. [CrossRef] [PubMed]

60. Van der Sluijs, M.; Kuhn, E.; Makoschey, B. A single vaccination with an inactivated bovine respiratory syncytial virus vaccine primes the cellular immune response in calves with maternal antibody. BMC Veter. Res. 2010, 6, 2. [CrossRef]

61. Blodörn, K.; Hägglund, S.; Fix, J.; Dubuquoy, C.; Makabi-Panzu, B.; Thom, M.; Karlsson, P.; Roque, J.-L.; Karlstam, E.; Pringle, J.; et al. Vaccine Safety and Efficacy Evaluation of a Recombinant Bovine Respiratory Syncytial Virus (BRSV) with Deletion of the SH Gene and Subunit Vaccines Based On Recombinant Human RSV Proteins: N-nanorings, P and M2-1, in Calves with Maternal Antibodies. PLoS ONE 2014, 9, e100392. [CrossRef] [PubMed]

62. Fulton, R.W.; E Briggs, R.; E Payton, M.; Confer, A.W.; Saliki, J.; Ridpath, J.F.; Burge, L.J.; Duff, G.C. Maternally derived humoral immunity to bovine viral diarrhea virus (BVDV) 1a, BVDV1b, BVDV2, bovine herpesvirus-1, parainfluenza-3 virus bovine respiratory syncytial virus, Mannheimia haemolytica and Pasteurella multocida in beef calves, antibody decline by half-life studies and effect on response to vaccination. Vaccine 2004, 22, 643-649. [CrossRef] [PubMed]

63. Richeson, J.T.; Hughes, H.D.; Broadway, P.R.; Carroll, J.A. Vaccination management of beef cattle: Delayed vaccination and Endotoxin stacking. Veter. Clin. Food Anim. 2019, 35, 575-592. [CrossRef]

64. Poulet, H.; Minke, J.; Pardo, M.C.; Juillard, V.; Nordgren, B.; Audonnet, J.-C. Development and registration of recombinant veterinary vaccines: The example of the canarypox vector platform. Vaccine 2007, 25, 5606-5612. [CrossRef] [PubMed]

65. Ellis, J.; Gow, S.; West, K.; Waldner, C.; Rhodes, C.; Mutwiri, G.; Rosenberg, H. Response of calves to challenge exposure with virulent bovine respiratory syncytial virus following intranasal administration of vaccines formulated for parenteral administration. J. Am. Veter. Med Assoc. 2007, 230, 233-243. [CrossRef]

66. Rossi, P.S.; Mattei, R.I.; Schllemer, N.R.; Thomaz, G.R.; Antunes, A.V.; Virmond, M.P.; Taube, M.J.; Bertagnon, H.G. The effect of bovine vaccines against respiratory viruses administered either intranasal or intramuscular on broncho-alveolar fluid cells of heifers. Veter. Q. 2021, 41, 97-106. [CrossRef] [PubMed]

67. Wright, P.F.; Karron, R.A.; Belshe, R.B.; Thompson, J.; Crowe, J.; Boyce, T.G.; Halburnt, L.L.; Reed, G.W.; Whitehead, S.S.; Anderson, E.L.; et al. Evaluation of a Live, Cold-Passaged, Temperature-Sensitive, Respiratory Syncytial Virus Vaccine Candidate in Infancy. J. Infect. Dis. 2000, 182, 1331-1342. [CrossRef] 
68. Henderson, D.A. The eradication of smallpox-An overview of the past, present, and future. Vaccine 2011, 29 (Suppl. 4), D7-D9. [CrossRef] [PubMed]

69. Anderson, J.; Baron, M.; Cameron, A.; Kock, R.; Jones, B.; Pfeiffer, D.; Mariner, J.; McKeever, D.; Oura, C.; Roeder, P.; et al. Rinderpest eradicated; what next? Veter. Rec. 2011, 169, 10-11. [CrossRef] [PubMed]

70. Roeder, P.L. Rinderpest: The end of cattle plague. Prev. Veter. Med. 2011, 102, 98-106. [CrossRef] [PubMed]

71. Sanders, B.; Koldijk, M.; Schuitemaker, H. Inactivated Viral Vaccines. In Infectious Disease and Vaccines Therapeutic Area; Springer: Berlin/Heidelberg, Germany, 2015; pp. 45-80.

72. Clem, A.S. Fundamentals of vaccine immunology. J. Glob. Infect. Dis. 2011, 3, 73-78. [CrossRef] [PubMed]

73. Ficht, T.A.; Kahl-McDonagh, M.M.; Arenas-Gamboa, A.M.; Rice-Ficht, A.C. Brucellosis: The case for live, attenuated vaccines. Vaccine 2009, 27, D40-D43. [CrossRef] [PubMed]

74. Goldsby, R.A.; Kindt, T.J.; Osborne, B.A.; Kuby, J. Immunology, 5th ed; Freeman: New York, NY, USA, 2003.

75. National Institute of Allergy and Infectious Disease. Vaccine Types. Available online: https://www.niaid.nih.gov/research/ vaccine-types (accessed on 10 October 2021).

76. Stevens, E.T.; Brown, M.S.; Burdett, W.W.; Bolton, M.W.; Nordstrom, S.T.; Chase, C.C.L. Efficacy of a Non-adjuvanted, Modifiedlive Virus Vaccine in Calves with Maternal Antibodies against a Virulent Bovine Viral Diarrhea Virus Type 2a Challenge Seven Months following Vaccination. Am. Assoc. Bov. Pract. 2011, 45, 23-31. [CrossRef]

77. Salerno-Gonçalves, R.; Sztein, M.B. Cell-mediated immunity and the challenges for vaccine development. Trends Microbiol. 2006, 14, 536-542. [CrossRef] [PubMed]

78. West, K.; Petrie, L.; Haines, D.M.; Konoby, C.; Clark, E.G.; Martin, K.; A Ellis, J. The effect of formalin-inactivated vaccine on respiratory disease associated with bovine respiratory syncytial virus infection in calves. Vaccine 1999, 17, 809-820. [CrossRef]

79. Vangeel, I.; Antonis, A.F.; Fluess, M.; Riegler, L.; Peters, A.R.; Harmeyer, S.S. Efficacy of a modified live intranasal bovine respiratory syncytial virus vaccine in 3-week-old calves experimentally challenged with BRSV. Veter. J. 2007, 174, 627-635. [CrossRef]

80. Xue, W.; Ellis, J.; Mattick, D.; Smith, L.; Brady, R.; Trigo, E. Immunogenicity of a modified-live virus vaccine against bovine viral diarrhea virus types 1 and 2, infectious bovine rhinotracheitis virus, bovine parainfluenza-3 virus, and bovine respiratory syncytial virus when administered intranasally in young calves. Vaccine 2010, 28, 3784-3792. [CrossRef] [PubMed]

81. Chamorro, M.F.; Palomares, R.A. Bovine Respiratory Disease Vaccination Against Viral Pathogens: Modified-Live Versus Inactivated Antigen Vaccines, Intranasal Versus Parenteral, What Is the Evidence? Veter. Clin. Food Anim. 2020, 36, 461-472. [CrossRef] [PubMed]

82. Kerkhofs, P.; Tignon, M.; Petry, H.; Mawhinney, I.; Sustronck, B. Immune responses to bovine respiratory syncytial virus (BRSV) following use of an inactivated BRSV-PI3-Mannheimia haemolytica vaccine and a modified live BRSV-BVDV vaccine. Veter. J. 2004, 167, 208-210. [CrossRef]

83. Knudson, C.J.; Hartwig, S.M.; Meyerholz, D.; Varga, S.M. RSV Vaccine-Enhanced Disease Is Orchestrated by the Combined Actions of Distinct CD4 T Cell Subsets. PLoS Pathog. 2015, 11, e1004757. [CrossRef] [PubMed]

84. Woolums, A.R.; Singer, R.S.; Boyle, G.A.; Gershwin, L.J. Interferon gamma production during bovine respiratory syncytial virus (BRSV) infection is diminished in calves vaccinated with formalin-inactivated BRSV. Vaccine 1999, 17, 1293-1297. [CrossRef]

85. Demasius, W.; Weikard, R.; Hadlich, F.; Müller, K.E.; Kühn, C. Monitoring the immune response to vaccination with an inactivated vaccine associated to bovine neonatal pancytopenia by deep sequencing transcriptome analysis in cattle. Veter. Res. 2013, 44, 93. [CrossRef]

86. Ellis, J.A.; Gow, S.P.; Mahan, S.; Leyh, R. Duration of immunity to experimental infection with bovine respiratory syncytial virus following intranasal vaccination of young passively immune calves. J. Am. Veter. Med Assoc. 2013, 243, 1602-1608. [CrossRef]

87. Patel, J.R.; Didlick, S.A. Evaluation of efficacy of an inactivated vaccine against bovine respiratory syncytial virus in calves with maternal antibodies. Am. J. Veter. Res. 2004, 65, 417-421. [CrossRef] [PubMed]

88. Kim, H.W.; Canchola, J.G.; Brandt, C.D.; Pyles, G.; Chanock, R.M.; Jensen, K.; Parrott, R.H. Respiratory syncytial virus disease in infants despite prior administration of antigenic inactivated vaccine. Am. J. Epidemiol. 1968, 89, 422-434, ISSN: 00029262 [CrossRef] [PubMed]

89. Antonis, A.F.G.; Schrijver, R.S.; Daus, F.; Steverink, P.J.G.M.; Stockhofe, N.; Hensen, E.J.; Langedijk, J.P.M.; van der Most, R.G. Vaccine-Induced Immunopathology during Bovine Respiratory Syncytial Virus Infection: Exploring the Parameters of Pathogenesis. J. Virol. 2003, 77, 12067-12073. [CrossRef] [PubMed]

90. Gershwin, L.J.; Schelegle, E.S.; Gunther, R.A.; Anderson, M.L.; Woolums, A.R.; Larochelle, D.R.; Boyle, G.A.; Friebertshauser, K.E.; Singer, R.S. A bovine model of vaccine enhanced respiratory syncytial virus pathophysiology. Vaccine 1998, 16, $1225-1236$. [CrossRef]

91. Kalina, W.V.; Woolums, A.R.; Gershwin, L.J. Formalin-inactivated bovine RSV vaccine influences antibody levels in bronchoalveolar lavage fluid and disease outcome in experimentally infected calves. Vaccine 2005, 23, 4625-4630. [CrossRef]

92. Delgado, M.F.; Coviello, S.; Monsalvo, A.C.; A Melendi, G.; Hernandez, J.Z.; Batalle, J.P.; Diaz, L.; Trento, A.; Chang, H.-Y.; Mitzner, W.; et al. Lack of antibody affinity maturation due to poor Toll-like receptor stimulation leads to enhanced respiratory syncytial virus disease. Nat. Med. 2009, 15, 34-41. [CrossRef]

93. Williams, P.D.; Paixão, G. On-farm storage of livestock vaccines may be a risk to vaccine efficacy: A study of the performance of on-farm refrigerators to maintain the correct storage temperature. BMC Veter. Res. 2018, 14, 1-7. [CrossRef] 
94. Saylor, K.; Gillam, F.; Lohneis, T.; Zhang, C. Designs of Antigen Structure and Composition for Improved Protein-Based Vaccine Efficacy. Front. Immunol. 2020, 11, 283. [CrossRef]

95. Ren, Q.; Xiong, H.; Li, Y.; Xu, R.; Zhu, C. Evaluation of an outside-the-Cold-Chain Vaccine Delivery Strategy in Remote Regions of Western China. Public Health Rep. 2009, 124, 745-750. [CrossRef]

96. Glenn, G.M.; Smith, G.; Fries, L.; Raghunandan, R.; Lu, H.; Zhou, B.; Thomas, D.N.; Hickman, S.P.; Kpamegan, E.; Boddapati, S.; et al. Safety and immunogenicity of a Sf9 insect cell-derived respiratory syncytial virus fusion protein nanoparticle vaccine. Vaccine 2013, 31, 524-532. [CrossRef] [PubMed]

97. Atuhaire, D.K.; Lieberman, D.; Marcotty, T.; Musoke, A.J.; Madan, D. An alternative cold chain for storing and transporting East Coast fever vaccine. Veter. Parasitol. 2020, 288, 109304. [CrossRef]

98. Gomez, M.; McCollum, J.; Wang, H.; Bachchhav, S.; Tetreau, I.; Gerhardt, A.; Press, C.; Kramer, R.M.; Fox, C.B.; Vehring, R. Evaluation of the stability of a spray-dried tuberculosis vaccine candidate designed for dry powder respiratory delivery. Vaccine 2021, 39, 5025-5036. [CrossRef]

99. Cameron, A.; McAllister, T.A. Antimicrobial usage and resistance in beef production. J. Anim. Sci. Biotechnol. 2016, 7, 1-22. [CrossRef] [PubMed]

100. Johnson, J.C.; Bryson, W.L.; Barringer, S.; Hunsaker, B.D. Evaluation of on-arrival versus prompted metaphylaxis regimes using ceftiofur crystalline free acid for feedlot heifers at risk of developing bovine respiratory disease. Veter. Ther. $2008,9,53-62$.

101. Van Boeckel, T.P.; Brower, C.; Gilbert, M.; Grenfell, B.T.; Levin, S.A.; Robinson, T.P.; Teillant, A.; Laxminarayan, R. Global trends in antimicrobial use in food animals. Proc. Natl. Acad. Sci. USA 2015, 112, 5649-5654. [CrossRef]

102. Department of Health; Department for Environment Food and Rural Affairs. UK Five Year Antimicrobial Resistance Strategy: 2013 to 2018. 2013. Available online: https:/ / www.gov.uk/government/uploads/system/uploads/attachment_data/file/2440 58/20130902_UK_5_year_AMR_strategy.pdf (accessed on 31 July 2016).

103. Singh, K.B.; Mehta, S. The clinical development process for a novel preventive vaccine: An overview. J. Postgrad. Med. 2016, 62, 4-11. [CrossRef] [PubMed]

104. Knight-Jones, T.J.D.; Edmond, K.; Gubbins, S.; Paton, D.J. Veterinary and human vaccine evaluation methods. Proc. R. Soc. B 2014, 281, 20132839. [CrossRef]

105. Draayer, H. Overview of currently approved veterinary vaccine potency testing methods and methods in development that do not require animal use. Procedia Vaccinol. 2011, 5, 171-174. [CrossRef]

106. Six, A.; Bellier, B.; Thomas-Vaslin, V.; Klatzmann, D. Systems biology in vaccine design. Microb. Biotechnol. 2012, 5, 295-304. [CrossRef] [PubMed]

107. Mackay, D.; Jimenez, C.M.; Ioannou, F.; Ilott, M. The contribution of field efficacy studies to the evaluation of applications for veterinary vaccines evaluated through the European Union centralised authorisation procedure. Biologicals 2021, 70, 7-16. [CrossRef]

108. The European Agency for the Evaluation of Veterinary Medicines. Guidance for Veterinary Medicinal Products; EMEA/CVMP/852/99FINAL; European Medicines Agency: Amsterdam, The Netherlands, 2001.

109. Levings, R.L.; Roth, J.A. Immunity to Bovine Herpesvirus 1: II. Adaptive Immunity and Vaccinology. Anim. Health Res. Rev. 2013, 14, 103-123. [CrossRef] [PubMed]

110. Guzman, E.; Taylor, G. Immunology of bovine respiratory syncytial virus in calves. Mol. Immunol. 2015, 66, 48-56. [CrossRef] [PubMed]

111. Sivakumar, S.; Safhi, M.M.; Kannadasan, M.; Sukumaran, N. Vaccine adjuvants - Current status and prospects on controlled release adjuvancity. Saudi Pharm. J. 2011, 19, 197-206. [CrossRef] [PubMed]

112. Di Pasquale, A.; Preiss, S.; Silva, F.M.D.O.E.; Garçon, N. Vaccine Adjuvants: From 1920 to 2015 and Beyond. Vaccines 2015, 3, 320-343. [CrossRef]

113. Mogil, J.S.; Crager, S.E. What should we be measuring in behavioral studies of chronic pain in animals? Pain 2004, 112, 12-15. [CrossRef]

114. Burakova, Y.; Madera, R.; McVey, S.; Schlup, J.R.; Shi, J. Adjuvants for Animal Vaccines. Viral Immunol. 2018, 31, 11-22. [CrossRef]

115. Parker, R.; Deville, S.; Dupuis, L.; Bertrand, F.; Aucouturier, J. Adjuvant formulation for veterinary vaccines: Montanide ${ }^{\mathrm{TM}}$ Gel safety profile. Procedia Vaccinol. 2009, 1, 140-147. [CrossRef]

116. Dar, P.; Kalaivanan, R.; Sied, N.; Mamo, B.; Kishore, S.; Suryanarayana, V.; Kondabattula, G. Montanide ISA ${ }^{\mathrm{TM}} 201$ adjuvanted FMD vaccine induces improved immune responses and protection in cattle. Vaccine 2013, 31, 3327-3332. [CrossRef]

117. Kolta, S.; Vishanath, B.S.; Dechamma, H.J.; Ganesh, K.; Suryanarayana, V.V.S.; Reddy, G.R. DNA vaccine (P1-2A-3C-pCDNA) co-administered with Bovine IL-18 gives protective immune response against Foot and Mouth Disease in cattle. Veter. Microbiol. 2016, 193, 106-115. [CrossRef]

118. Wilson-Welder, J.H.; Boggiatto, P.; Nally, J.E.; Wafa, E.; Alt, D.P.; Hornsby, R.L.; Frank, A.; Jones, D.E.; Olsen, S.C.; Bowden, N.B.; et al. Bovine immune response to leptospira antigen in different novel adjuvants and vaccine delivery platforms. Vaccine 2020, 38, 3464-3473. [CrossRef] [PubMed]

119. Gonçalves, V.S.; Santos, F.D.S.; Junior, A.G.D.S.; Piraine, R.E.A.; Rodrigues, P.R.C.; Brasil, C.L.; Conrad, N.L.; Leite, F.P.L. Recombinant bovine IL17A acts as an adjuvant for bovine herpesvirus vaccine. Res. Veter. Sci. 2021, 136, 185-191. [CrossRef] [PubMed] 
120. Carine, L.; Mathieu, B.; Laurent, R.; Jean-François, T.; Karl, W.; Stefan, R.; Gilles, M.; Jean-Jacques, L.; Pierre, K.; Letellier, C.; et al. Vaccination of calves using the BRSV nucleocapsid protein in a DNA prime-protein boost strategy stimulates cell-mediated immunity and protects the lungs against BRSV replication and pathology. Vaccine 2008, 26, 4840-4848. [CrossRef] [PubMed]

121. Hill, K.; Arsic, N.; Nordstrom, S.; Griebel, P.J. Immune memory induced by intranasal vaccination with a modified-live viral vaccine delivered to colostrum fed neonatal calves. Vaccine 2019, 37, 7455-7462. [CrossRef]

122. Lu, S. Heterologous prime-boost vaccination. Curr. Opin. Immun. 2009, 21, 346-351. [CrossRef]

123. Kardani, K.; Bolhassani, A.; Shahbazi, S. Prime-boost vaccine strategy against viral infections: Mechanisms and benefits. Vaccine 2016, 34, 413-423. [CrossRef] [PubMed]

124. Mapletoft, J.W.; Latimer, L.; Babiuk, L.A.; Hurk, S.V.D.L.-V.D. Intranasal Immunization of Mice with a Bovine Respiratory Syncytial Virus Vaccine Induces Superior Immunity and Protection Compared to Those by Subcutaneous Delivery or Combinations of Intranasal and Subcutaneous Prime-Boost Strategies. Clin. Vaccine Immunol. 2010, 17, 23-35. [CrossRef]

125. Miao, C.; Woolums, A.R.; Zarlenga, D.S.; Brown, C.C.; Brown, J.C.; Williams, S.M.; Scott, M.A. Effects of a single intranasal dose of modified-live bovine respiratory syncytial virus vaccine on cytokine messenger RNA expression following viral challenge in calves. Am. J. Veter. Res. 2004, 65, 725-733. [CrossRef]

126. Riffault, S.; Hägglund, S.; Guzman, E.; Näslund, K.; Jouneau, L.; Dubuquoy, C.; Valarcher, J.F. A Single Shot Pre-fusion-Stabilized Bovine RSV F Vaccine is Safe and E ff ective in Newborn Calves with Maternally Derived Antibodies. Vaccines 2020, 8, 231. [CrossRef] [PubMed]

127. Mawhinney, I.C.; Burrows, M.R. Protection against bovine respiratory syncytial virus challenge following a single dose of vaccine in young calves with maternal antibody. Veter. Rec. 2005, 156, 139-143. [CrossRef] [PubMed]

128. Loucks, M.E.; Morrill, J.L.; Dayton, A.D. Effect of prepartum vaccination with K99 Esherichia coli vaccine on maternal and calf blood antibody concentration and calf health. J. Dairy Sci. 1985, 68, 1841-1847. [CrossRef]

129. Kohara, J.; Hirai, T.; Mori, K.; Ishizaki, H.; Tsunemitsu, H. Enhancement of Passive Immunity with Maternal Vaccine against Newborn Calf Diarrhea. J. Veter. Med Sci. 1997, 59, 1023-1025. [CrossRef] [PubMed]

130. Dudek, K.; Bednarek, D.; Ayling, R.D.; Szacawa, E. Stimulation and analysis of the immune response in calves from vaccinated pregnant cows. Res. Veter.Sci. 2014, 97, 32-37. [CrossRef] [PubMed]

131. Baccili, C.C.; Silva, C.C.; Baldacim, P.; Greghi, G.F.; Vasconcellos, F.M.; Cacciacarro, B.S.; Gomes, V. Influence of maternal vaccination for the passive immune transfer against bovine respiratory viruses. Arq. Bras. Med. Veterinária Zootec. 2018, 70, 391-400. [CrossRef]

132. Tardon, M.C.; Allard, M.; Dutoit, V.; Dietrich, P.; Walker, P.R. Peptides as cancer vaccines. Curr. Opin. Pharmacol. 2019, 47, 20-26. [CrossRef]

133. Combadière, B.; Beaujean, M.; Chaudesaigues, C.; Vieillard, V. Peptide-Based Vaccination for Antibody Responses Against HIV. Vaccines 2019, 7, 105. [CrossRef] [PubMed]

134. Nakagami, H.; Koriyama, H.; Morishita, R. Peptide Vaccines for Hypertension and Diabetes Mellitus. Vaccines 2014, 2, 832-840. [CrossRef] [PubMed]

135. Belsham, G.J. Towards improvements in foot-and-mouth disease vaccine performance. Acta Veter. Scand. 2020, 62, 1-12. [CrossRef]

136. Paarlberg, P.L.; Lee, J.G.; Seitzinger, A.H. Potential revenue impact of an outbreak of foot-and-mouth disease in the United States. J. Am. Veter. Med Assoc. 2002, 220, 988-992. [CrossRef] [PubMed]

137. Greenwood, D.L.; Dynon, K.; Kalkanidis, M.; Xiang, S.; Plebanski, M.; Scheerlinck, J.-P.Y. Vaccination against foot-and-mouth disease virus using peptides conjugated to nano-beads. Vaccine 2008, 26, 2706-2713. [CrossRef]

138. Wang, C.Y.; Chang, T.Y.; Walfield, A.M.; Ye, J.; Shen, M.; Chen, S.P.; Li, M.C.; Lin, Y.L.; Jong, M.H.; Yang, P.C.; et al. Effective synthetic peptide vaccine for foot-and-mouth disease in swine. Vaccine 2002, 20, 2603-2610. [CrossRef]

139. Zhang, Z.; Pan, L.; Ding, Y.; Zhou, P.; Lv, J.; Chen, H.; Fang, Y.; Liu, X.; Chang, H.; Zhang, J.; et al. Efficacy of synthetic peptide candidate vaccines against serotype-A foot-and-mouth disease virus in cattle. Appl. Microbiol. Biotechnol. 2015, 99, 1389-1398. [CrossRef] [PubMed]

140. Bastien, N.; Taylor, G.; Thomas, L.H.; Wyld, S.G.; Simard, C.; Trudel, M. Immunization with a peptide derived from the G glycoprotein of bovine respiratory syncytial virus (BRSV) reduces the incidence of BRSV-associated pneumonia in the natural host. Vaccine 1997, 15, 1385-1390. [CrossRef]

141. Trudel, M.; Nadon, F.; Séguin, C.; Binz, H. Protection of BALE/c mice from respiratory syncytial virus infection by immunization with a synthetic peptide derived from the G glycoprotein. Virology 1991, 185, 749-757. [CrossRef]

142. Power, U.; Plotnicky-Gilquin, H.; Huss, T.; Robert, A.; Trudel, M.; Ståhl, S.; Uhlén, M.; Nguyen, T.N.; Binz, H. Induction of Protective Immunity in Rodents by Vaccination with a Prokaryotically Expressed Recombinant Fusion Protein Containing a Respiratory Syncytial Virus G Protein Fragment. Virology 1997, 230, 155-166. [CrossRef] [PubMed]

143. Jaberolansar, N.; Chappell, K.J.; Watterson, D.; Bermingham, I.M.; Toth, I.; Young, P.R.; Skwarczynski, M. Induction of high titred, non-neutralising antibodies by self-adjuvanting peptide epitopes derived from the respiratory syncytial virus fusion protein. Sci. Rep. 2017, 7, 1-11. [CrossRef] [PubMed]

144. Trudel, M.; Nadon, F.; Séguin, C.; Simard, C.; Lussier, G. Experimental polyvalent ISCOMs subunit vaccine induces antibodies that neutralize human and bovine respiratory syncytial virus. Vaccine 1989, 7, 12-16. [CrossRef] 
145. Hägglund, S.; Hu, K.; Vargmar, K.; Poré, L.; Olofson, A.-S.; Blodörn, K.; Anderson, J.; Ahooghalandari, P.; Pringle, J.; Taylor, G.; et al. Bovine respiratory syncytial virus ISCOMs-Immunity, protection and safety in young conventional calves. Vaccine 2011, 29, 8719-8730. [CrossRef]

146. Franz, J.; Hampl, J.; Stepanek, J.; Ŝmid, B. Preparation of Immunostimulating Complexes (ISCOM) Containing Bovine Herpesvirus 1 Proteins. Acta Veter. Brno 1992, 61, 37-41. [CrossRef]

147. Kamstrup, S.; Roensholt, L.; Jensen, M.; Dalsgaard, K. Production of a highly immunogenic subunit ISCOM vaccine against Bovine Viral Diarrhea Virus. Vaccine 1999, 17, 1057-1064. [CrossRef]

148. Crisci, E.; Bárcena, J.; Montoya, M. Virus-like particles: The new frontier of vaccines for animal viral infections. Veter. Immunol. Immunopathol. 2012, 148, 211-225. [CrossRef] [PubMed]

149. Loy, J.D.; Gander, J.; Mogler, M.; Veen, R.V.; Ridpath, J.; Harris, D.H.; Kamrud, K. Development and evaluation of a replicon particle vaccine expressing the E2 glycoprotein of bovine viral diarrhea virus (BVDV) in cattle. Virol. J. 2013, 10, 35. [CrossRef] [PubMed]

150. Zolnik, B.S.; González-Fernández, Á.; Sadrieh, N.; Dobrovolskaia, M.A. Minireview: Nanoparticles and the Immune System. Endocrinology 2010, 151, 458-465. [CrossRef] [PubMed]

151. Mansoor, F.; Earley, B.; Cassidy, J.P.; Markey, B.; Doherty, S.; Welsh, M.D. Comparing the immune response to a novel intranasal nanoparticle PLGA vaccine and a commercial BPI3V vaccine in dairy calves. BMC Veter. Res. 2015, 11, 1-11. [CrossRef] [PubMed]

152. Kavanagh, O.V.; Adair, B.M.; Welsh, M.; Earley, B. Immunogenetic responses in calves to intranasal delivery of bovine respiratory syncytial virus (BRSV) epitopes encapsulated in poly (DL-lactide-co-glycolide) microparticles. Res. Veter. Sci. 2013, 95, 786-793. [CrossRef] [PubMed]

153. Cerbu, C.; Kah, M.; White, J.C.; Astete, C.E. Fate of Biodegradable Engineered Nanoparticles Used in Health Perspective. Molecules 2021, 26, 523. [CrossRef] [PubMed]

154. Dhama, K.; Mahendran, M.; Gupta, P.K.; Rai, A. DNA vaccines and their applications in veterinary practice: Current perspectives. Veter. Res. Commun. 2008, 32, 341-356. [CrossRef]

155. Oshop, G.; Elankumaran, S.; Heckert, R. DNA vaccination in the avian. Veter. Immunol. Immunopathol. 2002, 89, 1-12. [CrossRef]

156. Dunham, S.P. The application of nucleic acid vaccines in veterinary medicine. Res. Veter. Sci. 2002, 73, 9-16. [CrossRef]

157. Patial, S.; Chaturvedi, V.; Rai, A.; Saini, M.; Chandra, R.; Saini, Y.; Gupta, P.K. Virus neutralizing antibody response in mice and dogs with a bicistronic DNA vaccine encoding rabies virus glycoprotein and canine parvovirus VP2. Vaccine 2007, 25, 4020-4028. [CrossRef]

158. Babiuk, S.; Babiuk, L.A. DNA vaccines. In Encyclopedia of Virology, 3rd ed.; Elsevier: Amsterdam, The Netherlands, 2008; pp. $51-55$.

159. Nobiron, I.; Thompson, I.; Brownlie, J.; Collins, M.E. DNA vaccination against bovine viral diarrhoea virus induces humoral and cellular responses in cattle with evidence for protection against viral challenge. Vaccine 2003, 21, 2082-2092. [CrossRef]

160. Ulmer, J.B.; Donnelly, J.J.; Parker, S.E.; Rhodes, G.H.; Felgner, P.L.; Dwarki, V.J.; Liu, M.A. Heterolgous protection against influenza by injection of DNA encoding a viral protein. Science 1993, 259, 1745-1749. [CrossRef] [PubMed]

161. Hamers, C.; Juillard, V.; Fischer, L. DNA Vaccination against Pseudorabies Virus and Bovine Respiratory Syncytial Virus Infections of Young Animals in the Face of Maternally Derived Immunity. J. Comp. Pathol. 2007, 137, S35-S41. [CrossRef] [PubMed]

162. Taylor, G.; Bruce, C.; Barbet, A.F.; Wyld, S.G.; Thomas, L.H. DNA vaccination against respiratory syncytial virus in young calves. Vaccine 2005, 23, 1242-1250. [CrossRef] [PubMed]

163. Schrijver, R.S.; Langedijk, J.P.; Keil, G.M.; Middel, W.G.; Maris-Veldhuis, M.; Van Oirschot, J.T.; A Rijsewijk, F. Immunization of cattle with a BHV1 vector vaccine or a DNA vaccine both coding for the G protein of BRSV. Vaccine 1997, 15, 1908-1916. [CrossRef]

164. Kornuta, C.A.; Langellotti, C.A.; Bidart, J.E.; Soria, I.; Quattrocchi, V.; Gammella, M.; Valenzuela, F.C.; Mignaqui, A.C.; Ferraris, S.; Charleston, B.; et al. A plasmid encoding the extracellular domain of CD40 ligand and Montanide ${ }^{\mathrm{TM}}$ GEL01 as adjuvants enhance the immunogenicity and the protection induced by a DNA vaccine against BoHV-1. Vaccine 2021, 39, 1007-1017. [CrossRef]

165. Redding, L.; Weiner, D.B. DNA vaccines in veterinary use. Expert Rev. Vaccines 2009, 8, 1251-1276. [CrossRef]

166. Jackson, N.A.C.; Kester, K.E.; Casimiro, D.; Gurunathan, S.; DeRosa, F. The promise of mRNA vaccines: A biotech and industrial perspective. npj Vaccines 2020, 5, 1-6. [CrossRef]

167. Dolgin, E. The tangled history of mRNA vaccines. Nature 2021, 597, 318-324. [CrossRef] [PubMed]

168. Pardi, N.; Hogan, M.; Pelc, R.; Muramatsu, H.; Andersen, H.; DeMaso, C.R.; Dowd, K.A.; Sutherland, L.L.; Scearce, R.M.; Parks, R.; et al. Zika virus protection by a single low-dose nucleoside-modified mRNA vaccination. Nature 2017, 543, 248-251. [CrossRef] [PubMed]

169. Petsch, B.; Schnee, M.; Vogel, A.; Lange, E.; Hoffmann, B.; Voss, D.; Schlake, T.; Thess, A.; Kallen, K.-J.; Stitz, L.; et al. Protective efficacy of in vitro synthesized, specific mRNA vaccines against influenza A virus infection. Nat. Biotechnol. 2012, 30, 1210-1216. [CrossRef] [PubMed]

170. Alberer, M.; Gnad-Vogt, U.; Hong, H.S.; Mehr, K.T.; Backert, L.; Finak, G.; Gottardo, R.; Bica, M.A.; Garofano, A.; Koch, S.D.; et al. Safety and immunogenicity of a mRNA rabies vaccine in healthy adults: An open-label, non-randomised, prospective, first-in-human phase 1 clinical trial. Lancet 2017, 390, 1511-1520. [CrossRef]

171. Batra, S.A.; Shanthalingam, S.; Donofrio, G.; Haldorson, G.J.; Chowdhury, S.; White, S.N.; Srikumaran, S. Immunization of bighorn sheep against Mannheimia haemolytica with a bovine herpesvirus 1-vectored vaccine. Vaccine 2017, 35, 1630-1636. [CrossRef] 
172. Bilge, S.; Touraj, D.; Farzani, A.; Dogan, F.; Akkutay, Z.; Aykut, Y. Development of a BoHV—4 viral vector expressing tgD of BoHV-1 and evaluation of its immunogenicity in mouse model. Braz. J. Microbiol. 2021, 52, 1119-1133. [CrossRef]

173. Chowdhury, S.I.; Pannhorst, K.; Sangewar, N.; Pavulraj, S.; Wen, X.; Stout, R.W.; Mwangi, W.; Paulsen, D.B. BoHV-1-Vectored BVDV-2 Subunit Vaccine Induces BVDV Cross-Reactive Cellular Immune Responses and Protects against BVDV-2 Challenge. Vaccines 2021, 9, 46. [CrossRef] [PubMed]

174. Taylor, G.; Thomas, L.H.; Wyld, S.G.; Wertz, G.W.; Hardy, R.; Cook, R.S.; Furze, J.M.; Lerch, R. Recombinant vaccinia viruses expressing the $\mathrm{F}, \mathrm{G}$ or $\mathrm{N}$, but not the $\mathrm{M} 2$, protein of bovine respiratory syncytial virus (BRSV) induce resistance to BRSV challenge in the calf and protect against the development of pneumonic lesions. J. Gen. Virol. 1997, 78, 3195-3206. [CrossRef]

175. Antonis, A.F.; van der Most, R.G.; Suezer, Y.; Stockhofe-Zurwieden, N.; Daus, F.; Sutter, G.; Schrijver, R.S. Vaccination with recombinant modified vaccinia virus Ankara expressing bovine respiratory syncytial virus (bRSV) proteins protects calves against RSV challenge. Vaccine 2007, 25, 4818-4827. [CrossRef]

176. Nelson, G.; Marconi, P.; Periolo, O.; La Torre, J.; Alvarez, M.A. Immunocompetent truncated E2 glycoprotein of bovine viral diarrhea virus (BVDV) expressed in Nicotiana tabacum plants: A candidate antigen for new generation of veterinary vaccines. Vaccine 2012, 30, 4499-4504. [CrossRef]

177. Faye, L.; Gomord, V. Editorial Success stories in molecular farming-A brief overview. Plant Biotechnol. J. 2010, 8, 525-528. [CrossRef]

178. Rybicki, E.P. Plant-made vaccines for humans and animals. Plant Biotechnol. J. 2010, 8, 620-637. [CrossRef]

179. Taylor, G.; Wyld, S.G.; Keil, G.; I Morrison, W.; Hensen, E.; Cook, R.S.; A Rijsewijk, F.; Gaddum, R.M.; Thomas, L.H.; Van Oirschot, J.T. Resistance to bovine respiratory syncytial virus (BRSV) induced in calves by a recombinant bovine herpesvirus-1 expressing the attachment glycoprotein of BRSV. J. Gen. Virol. 1998, 79, 1759-1767. [CrossRef]

180. Briggs, R.E.; Tabatabai, L.B.; Tatum, F.M. Microbial Pathogenesis Mucosal and parenteral vaccination against pneumonic pasteurellosis in cattle with a modi fi ed-live in-frame lktA deletion mutant of Mannheimia haemolytica. Microb. Pathog. 2012, 52, 302-309. [CrossRef] [PubMed]

181. AFBI/DAERA. All-Island Disease Surveillance Report: A Joint AFBI/DAFM Veterinary Laboratories Report; AFBI: Belfast, UK, 2016.

182. Pretty, J.; Sutherland, W.J.; Ashby, J.; Auburn, J.; Baulcombe, D.; Bell, M.; Bentley, J.; Bickersteth, S.; Brown, K.; Burke, J.; et al. The top 100 questions of importance to the future of global agriculture. Int. J. Agric. Sustain. 2010, 8, 219-236. [CrossRef]

183. Daly, P.A. Agricultural employment: Has the decline ended? Mon. Labor Rev. 1981, 104, 11-17.

184. Roser, M. Employment in agriculture. Our World in Data. 2013. Available online: https:/ / ourworldindata.org/employment-inagriculture (accessed on 27 September 2021).

185. Schneider, U.; Havlík, P.; Schmid, E.; Valin, H.; Mosnier, A.; Obersteiner, M.; Böttcher, H.; Skalský, R.; Balkovič, J.; Sauer, T.; et al. Impacts of population growth, economic development, and technical change on global food production and consumption. Agric. Syst. 2011, 104, 204-215. [CrossRef]

186. Department for Environment Food and Rural Affairs. Total Income from Farming in the United Kingdom, First Estimate for 2020; Department for Environment Food and Rural Affairs: Bristol, UK, 2021.

187. Allen, M. Northern Ireland's Agri-Food Sector-Background and possible 'Brexit' Considerations. 2016. Available online: http:/ / www.niassembly.gov.uk/globalassets/documents/raise/publications/2016-2021/2016/aera/6616.pdf (accessed on 16 July 2017).

188. Playfair, D. Northern Ireland Agri-Food Sector-Agriculture, Fishing and Forestry. 2018. Available online: https://www.daerani.gov.uk/sites/default/files/publications/daera/Key\%20Statistics\%20for\%202018.pdf (accessed on 22 March 2019).

189. Smith, R.A.; Step, D.L.; Woolums, A.R. Bovine Respiratory Disease Looking Back and Looking Forward, What Do We See? Veter. Clin. Food Anim. 2020, 36, 239-251. [CrossRef] 